\title{
Physical-chemical wastewater treatment in Arctic conditions
}

\author{
Ekaterina Glushchenko ${ }^{1, *}$, Elena Vialkova ${ }^{1}$, Olga Sidorenko $^{1}$, and Anastasia Fugaeva ${ }^{1}$ \\ ${ }^{1}$ Industrial University of Tyumen, Volodarskogo Street 38, Tyumen, 625000, Russia
}

\begin{abstract}
The biological wastewater treatment problem of the small villages located in the Arctic zone is considered. The purpose of this research is to study the alternative wastewater treatment method in Northern settlements. Standard research methods were used: gravimetric and photometric methods of liquid analysis to achieve this goal. This article presents the physical-chemical wastewater treatment method, consisted of coagulation proses, oxidation, sand and sorption filtration. As a result of the laboratory research, the effects of pollutants removal are 96.6\% (COD), $82.4 \%$ (ammonium) and $97.1 \%$ (nitrates). These effects were achieved by the technological scheme that includes a coagulation, two-stage sequential oxidation with potassium permanganate and ozone, and intermediate filtration too. The brands of coagulant and flocculant were selected, as well as their optimal doses.
\end{abstract}

\section{Introduction}

The large area of the Russian Federation is situated in the arctic (or close to arctic) nature conditions and Tyumen Region (the largest region in Russia) is not exception. This region is the leading oil and gas producer in own country. The severe climate conditions, frozen soil and swamps cause the serious problems while designing, construction and exploitation of the various objects in there. In the Khanty-Mansi and Yamal-Nenets Autonomous Districts, there are more than 100 small settlements located far from the major centres and having the decentralized sewage systems. The exploitation of the biological treatment facilities, based on an aerobic treatment, presents some difficulties due to severe climate, frozen soils and swamps. There is no any wastewater treatment plants (WWTP) in the many small towns and settlements. The domestic wastewaters are accumulated in the septic tanks and periodically dumped to the soil or water objects without any treatment. Such approach to wastewater treatment negatively influences the environment ecology.

Exploitation of the small wastewater treatment facilities is rather difficult to realize in north climate for small settlements. The low temperatures (from $+2{ }^{\circ} \mathrm{C}$ to $+7^{\circ} \mathrm{C}$ ) of wastewater coming to the treatment plants significantly affect the biochemical treatment processes. Moreover, the initial wastes have high concentration of the organic matters due to low norm of effluents discharge (80-90 1/day for person) and the infiltration of

* Corresponding author: ekaterina.gluschenko.1997@ mail.ru 
wastewater to the soil while accumulating in the septic tanks. The average effectiveness of the treatment plant work significantly depends on their capacity and is approximately from 70 to $90 \%$ [1].

The Europe countries pay great attention to the small wastewater treatment plants' functioning, the complex assessment of their operation and the creation of their reconstruction government programs [2-4]. For example, the stabilization ponds, which operate in the periodical effluents discharge mode, have become widespread in the north settlements of Canada and Norway. Besides, the stabilization ponds can be used as a tertiary treatment after aerobic biofilter that reduces the concentration of $\mathrm{BOD}_{5}$ by $96 \%$, nitrite content by $60 \%$ and phosphate content by $90 \%$ [5-7].

A number of scientists [8-12] suggest the anaerobic technologies or the biochemical oxidation as an alternative to the aerobic treatment. An additional product of such treatment is biogas, which can be used as an energy source. Biogas is the mixture of gases produced by the breakdown of organic matter in the absence of oxygen (anaerobically), primarily consisting of methane and carbon dioxide. Among bioelectrochemical technologies the microbial fuel cells (MFC) and the electrolysis cells (MEC) have become widespread for removing the organic matters from the wastes: they can decrease the COD concetration on $80 \%$. An another variant of the wastewater treatment is the block module plants, for example, in Sweden and Norway. The main element of such plants is the either biochemical aerobic module (SBR-reactor, aerotank, biofilter) or the physical-chemical module. However, according to authors [11-12], the real water contamination concentrations often do not correspond to the standard requirements.

Nowadays, the significant researches on the effective physical-chemical methods of wastewater treatment, which are simple for exploitation in the north climate, are conducted [13-22]. Among the main oxidation technologies, the following ones are the most widespread: ozonation + hydrogen peroxide (probably with catalyst); electrochemical oxidation methods (electrocoagulation, electroflotation); Fenton process; ozonation + ultraviolet radiation.

However, the required effects of the organic contaminations removal from domestic wastewater cannot be always achieved while realizing the above-mentioned technologies. According to published data, almost all technological schemes of the wastewater treatment plants without biological module have the problems with COD and nitrogen compounds removal. That is why the physical-chemical methods are usually used for the tertiary treatment of the industrial wastes with the low organic matters' concentrations. At the same time, these methods have several advantages, such as susceptibility to unit wastewaters discharge, the simple exploitation and effectiveness at the low wastes temperatures.

In conjunction with the foregoing, the target of this work is the research of physicalchemical methods for the domestic wastewater treatment. The new technology scheme is recommended for the WWTP of the small north settlements.

\section{Materials and methods}

The object of the research is the wastewater, taken from receiving part of dump tank, where effluents from small settlements are brought to.

The following qualitative indices of wastewater were chosen as the most problem ones: the concentration of suspended matters, chemical oxygen demand (COD), ammonium-ions concentration $\left(\mathrm{NH}_{4}^{+}\right)$, concertation of nitrate-ions $\left(\mathrm{NO}_{3}{ }^{-}\right)$and $\mathrm{pH}$.

These wastes qualitative indices were determined for initial wastewater before the treatment and after every stage of the treatment according to the standard methods.

$\mathrm{pH}$ was measured with a potentiometric method by a $\mathrm{pH}-$ meter $\mathrm{pH}-150 \mathrm{MI}$. 
The concentration of suspended matters was determined gravimetrically by measuring the mass of solids left on the filter.

To measure the COD, concentration of ammonium and nitrates the photometrical method was used. For COD measuring the potassium dichromate, silver sulphate $\left(3 \mathrm{~cm}^{3}\right)$ and mercuric sulphate $\left(0.2 \mathrm{~cm}^{3}\right)$ were mixed with the water sample $\left(2 \mathrm{~cm}^{3}\right)$ in the glass vial. After that, the vials content was heated two hours at temperature $150^{\circ} \mathrm{C}$ in a termoreactor, and then a fluid analyzer "Fluorat- $0.2 \mathrm{M}$ " scanned the COD-index photometrically.

The concentration of ammonium and nitrates was determined by a spectrophotometer PE-5400VI. For measuring ammonium-ions concentration, potassium-sodium tartrate (1 $\left.\mathrm{cm}^{3}\right)$ and Nessler's reagent $\left(1 \mathrm{~cm}^{3}\right)$ were added to the water sample $(50 \mathrm{~cm} 3)$. After 10 minutes contact of reagents the ammonium ions amount in the wastewater was determined.

For measuring the nitrates-ions concentration, the water sample $\left(10 \mathrm{~cm}^{3)}\right.$ and the salicylic acid $(2 \mathrm{~cm} 3)$ were mixed and input to a porcelain dish. Then the mixture was evaporated on a heating bath. After cooling the solid residual was dissolved during 10 minutes in $2 \mathrm{~cm}^{3}$ of sulphuric acid, and then to the solution were added $10 \mathrm{~cm}^{3}$ of distilled water and $15 \mathrm{~cm}^{3}$ of potassium-sodium tartrate and sodium hydroxide mixture. The solution, received in the porcelain evaporation dish, was transferred to a volumetric flask of $50 \mathrm{~cm}^{3}$ volume. Then, the nitrate-ions concentration was determined.

The wastewater samples were taken to the 5-litres bottles, and then in initial wastewater all qualitative indices were measured.

For physical-chemical methods researching, the following technological scheme of the wastewater treatment was suggested: the initial coagulation (for removal most suspended matters and partially organic matters) and further oxidation with the reagents (for removing residual part of organic contaminations and nitrogen compounds).

For research' conducting the five coagulants were chosen: 3 of them are aluminumcontaining and 2 of them are iron-containing:

- aluminium sulphate, $3.64 \%$ solution;

- aluminium oxychloride, $3.53 \%$ solution;

- aluminium polyoxychloride "Akva-Aurat 30", 5\% solution;

- ferrous sulphatr, $5 \%$ solution;

- ferric chloride, $5 \%$ solution.

Following flocculants were chosen for the experiment:

- polyacrylamide, $0.5 \%$ solution;

- Praestol 650 TR, $1 \%$ solution.

The initial wastewater sample was put into a cylinder of $250 \mathrm{~cm}^{3}$ volume, where coagulant and after 2 minutes flocculant were added to. After intensive mixing during 2 minutes with a stirring rod, the wastewater sample was settled during 20 minutes for floc formation and further their sedimentation. For suspended matters removing the wastewater samples were filtered through a layer of quartz sand (the fraction diameter is $0.8-2 \mathrm{~mm}$ ). When all wastewater samples were filtered, the qualitative indices were measured.

For removing from filtrated wastewater the organic compounds and contaminations, caused by nitrogen compounds (ammonium-ion, nitrates), the oxidation method was used. There were two reagents for oxidation: the potassium permanganate and sodium hypochlorite. Moreover, the different methods of oxidation intensification were examined.

For conducting the experiment, necessary quantity of the reagent-oxidant was added to $0.5 \mathrm{dm}^{3}$ of the filtrated wastewater sample, and contact of wastewater and reagent was provided during 20 minutes. As time passed the sample, was two-staged filtered: first through a layer of quartz sand (the fraction diameter is $1 \mathrm{~mm}$ ), and then through a layer of activated carbon (the fraction diameter is $0.5 \mathrm{~mm}$ ).

However, because of not full reduction of the organic matters, 3 methods of oxidation intensification as well as double oxidation were examined: 
1)Wastewater heating to $60^{\circ} \mathrm{C}$

After adding an optimal dose of reagent-oxidant to the filtrated wastewater sample $(0.5$ $\mathrm{dm}^{3}$ ) and intensive mixing one, wastewater was heated to $60^{\circ} \mathrm{C}$ during 20 minutes. A thermometer controlled the temperature of the wastewater samples. After heating the wastewater samples were two-staged filtered through the sand and carbon filters.

2)Wastewater treatment by microwave radiation at $60^{\circ} \mathrm{C}$

After adding optimal dose of the reagent-oxidant into filtrated wastewater $\left(0.5 \mathrm{dm}^{3}\right)$ and intensive mixing, the wastewater sample was heated to $60^{\circ} \mathrm{C}$ during 2 minutes in a microwave oven Mystery MMW-2010 (capacity $800 \mathrm{~W}$ ). Then the sample was cooled to $20^{\circ} \mathrm{C}$. After cooling the water sample was two-staged filtered through the sand and carbon filters.

After adding an optimal dose of the reagent-oxidant to filtrated wastewater $\left(0.5 \mathrm{dm}^{3}\right)$ and intensive mixing, the water sample was aerated during 20 minutes by a compressor SCHEGO Optimal (capacity 2500 1/hour). After aeration the water sample was two-staged filtered through sand and carbon filters.

3)Double oxidation by ozonation.

After adding an optimal dose of the reagent-oxidant to filtrated wastewater $\left(0.5 \mathrm{dm}^{3}\right)$ and intensive mixing, 20 minutes contact was provided and wastewater was filtered through sand filter. The filtrated water sample was ozonized during 30 minutes by a domestic ozonizer Anion Ozonizer HO-01 (capacity $400 \mathrm{mg}$ /hour). After ozonation the wastewater sample was filtered through the carbon filter.

\section{Results}

The qualitative composition of the initial wastewater sample is shown in Table 1.

Table 1. Qualitative composition of initial wastewater.

\begin{tabular}{|c|c|c|}
\hline Index & $\begin{array}{c}\text { Unit of } \\
\text { measurement }\end{array}$ & Measurement result \\
\hline $\mathrm{pH}$ & - & 7.34 \\
\hline Suspended matters & $\mathrm{mg} / \mathrm{dm}^{3}$ & 977 \\
\hline $\mathrm{COD}$ & $\mathrm{mgO} / \mathrm{dm}^{3}$ & 1220 \\
\hline Ammonium-ion & $\mathrm{mg} / \mathrm{dm}^{3}$ & 151.0 \\
\hline Nitrate-ion & $\mathrm{mg} / \mathrm{dm}^{3}$ & 5.10 \\
\hline
\end{tabular}

According to Table 1 concentrations of most components are higher than the standard requirements, which is typical for domestic wastewaters of most human settlements.

The results of wastewater coagulation and filtration with the different coagulants are shown in Table 2-4.

Table 2. Qualitative composition of wastewater after coagulation with aluminium sulphate.

\begin{tabular}{|c|c|c|c|c|}
\hline \multirow{2}{*}{ Index } & \multicolumn{4}{|c|}{ Dose, $\mathrm{mg} / \mathrm{dm}^{3}$} \\
\cline { 2 - 5 } & 30 & 50 & 90 & 200 \\
\hline $\mathrm{COD}, \mathrm{mgO} / \mathrm{dm}^{3}$ & 1078 & 556 & 440 & 420 \\
\hline $\mathrm{NH}_{4}{ }^{+}, \mathrm{mg} / \mathrm{dm}^{3}$ & 149.5 & 152 & 151 & 148 \\
\hline $\mathrm{NO}_{3}{ }^{-}, \mathrm{mg} / \mathrm{dm}^{3}$ & 1.79 & 1.38 & 2.13 & 1.56 \\
\hline
\end{tabular}

Table 3. Qualitative composition of wastewater after coagulation with aluminium oxychloride.

\begin{tabular}{|c|c|c|c|c|}
\hline \multirow{2}{*}{ Index } & \multicolumn{4}{|c|}{ Dose, $\mathrm{mg} / \mathrm{dm}^{3}$} \\
\cline { 2 - 5 } & 30 & 50 & 90 & 200 \\
\hline $\mathrm{COD}, \mathrm{mgO} / \mathrm{dm}^{3}$ & 504 & 610 & 508 & 750 \\
\hline $\mathrm{NH}_{4}{ }^{+}, \mathrm{mg} / \mathrm{dm}^{3}$ & 152.5 & 150.5 & 151.0 & 152.5 \\
\hline
\end{tabular}




\begin{tabular}{|l|l|l|l|l|}
$\mathrm{NO}_{3}^{-}, \mathrm{mg} / \mathrm{dm}^{3}$ & 2.06 & 1.81 & 1.30 & 0.78 \\
\hline
\end{tabular}

Table 4. Qualitative composition of wastewater after coagulation with aluminium polyoxychloride (“Akva-Aurat 30").

\begin{tabular}{|c|c|c|c|c|}
\hline \multirow{2}{*}{ Index } & \multicolumn{4}{|c|}{ Dose, $\mathrm{mg} / \mathrm{dm}^{3}$} \\
\cline { 2 - 5 } & 30 & 50 & 90 & 200 \\
\hline $\mathrm{COD}, \mathrm{mgO} / \mathrm{dm}^{3}$ & 714 & 436 & 480 & 706 \\
\hline $\mathrm{NH}_{4}^{+}, \mathrm{mg} / \mathrm{dm}^{3}$ & 148 & 150.5 & 150.5 & 148 \\
\hline $\mathrm{NO}_{3}{ }^{-}, \mathrm{mg} / \mathrm{dm}^{3}$ & 1.21 & 1.62 & 1.89 & 1.19 \\
\hline
\end{tabular}

The dependence of COD concentration from the dose of aluminum-containing coagulant is shown on Figure 1.

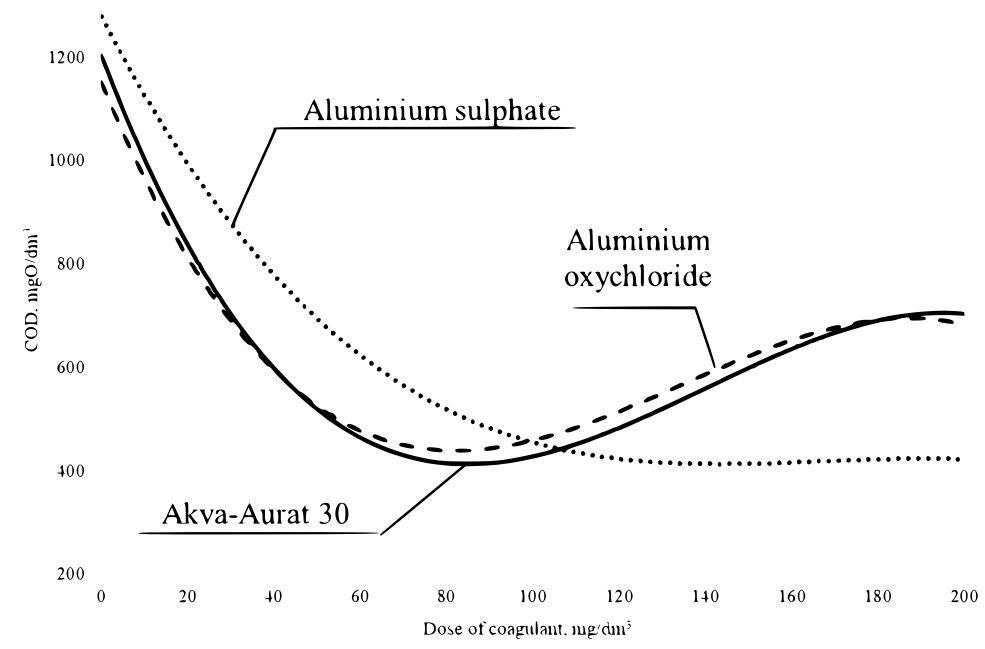

Fig. 1. The dependence of COD concentration from the dose of aluminum-containing coagulant.

For coagulation intensification, the flocculant was added to wastewater after coagulant. The flocculant and its optimal dose choice was made by the experiment results, shown in Table 5 and 6.

Table 5. The COD removal after adding flocculant, in proportion to the initial concentration.

\begin{tabular}{|c|c|c|c|c|c|}
\hline \multirow{3}{*}{ Flocculant } & \multirow{3}{*}{$\begin{array}{l}\text { Initial } \\
\mathrm{COD} \\
\mathrm{mgO} / \mathrm{dm}^{3}\end{array}$} & \multicolumn{4}{|c|}{ Dose of flocculant } \\
\hline & & \multicolumn{2}{|c|}{$0.5 \mathrm{mg} / \mathrm{dm}^{3}$} & \multicolumn{2}{|c|}{$1 \mathrm{mg} / \mathrm{dm}^{3}$} \\
\hline & & $\begin{array}{c}\mathrm{COD}, \\
\mathrm{mgO} / \mathrm{dm}^{3}\end{array}$ & $\begin{array}{c}\text { Treatment } \\
\text { effect }\end{array}$ & $\begin{array}{c}\mathrm{COD}, \\
\mathrm{mgO} / \mathrm{dm}^{3}\end{array}$ & $\begin{array}{c}\text { Treatment } \\
\text { effect }\end{array}$ \\
\hline Polyacrylamide & 1220 & 429 & $64.8 \%$ & 365 & $70.1 \%$ \\
\hline Praestol 650TR & 1220 & 392 & $67.9 \%$ & 403 & $67 \%$ \\
\hline
\end{tabular}

Table 6. The nitrates removal after adding flocculant, in proportion to the initial concentration.

\begin{tabular}{|c|c|c|c|c|c|}
\hline \multirow{3}{*}{ Flocculant } & \multirow{3}{*}{$\begin{array}{c}\mathrm{Initial} \mathrm{NO}_{3}^{-} \\
, \mathrm{mg} / \mathrm{dm}^{3}\end{array}$} & \multicolumn{4}{|c|}{ Dose of flocculant } \\
\hline & & \multicolumn{2}{|c|}{$0.5 \mathrm{mg} / \mathrm{dm}^{3}$} & \multicolumn{2}{|c|}{$1 \mathrm{mg} / \mathrm{dm}^{3}$} \\
\hline & & $\begin{array}{l}\mathrm{NO}_{3}^{-} \\
\mathrm{mg} / \mathrm{dm}^{3}\end{array}$ & $\begin{array}{c}\text { Treatment } \\
\text { effect }\end{array}$ & $\begin{array}{l}\mathrm{NO}_{3}^{-}, \\
\mathrm{mg} / \mathrm{dm}^{3}\end{array}$ & $\begin{array}{c}\text { Treatment } \\
\text { effect }\end{array}$ \\
\hline Polyacrylamide & 5.1 & 1.54 & $69.8 \%$ & 1.57 & $69.2 \%$ \\
\hline Praestol 650TR & 5.1 & 1.25 & $75.5 \%$ & 1.23 & $75.9 \%$ \\
\hline
\end{tabular}

The results of wastewater oxidation with potassium permanganate and sodium hypochlorite, and further two-staged filtration are shown in Table 7 and 8. 
Table 7. The wastewaters oxidation with potassium permanganate.

\begin{tabular}{|c|c|c|c|c|}
\hline \multirow{2}{*}{ Index } & \multicolumn{4}{|c|}{ Dose, $\mathrm{mg} / \mathrm{dm}^{3}$} \\
\cline { 2 - 5 } & $\mathbf{5}$ & $\mathbf{1 0}$ & $\mathbf{2 0}$ & $\mathbf{5 0}$ \\
\hline $\mathrm{pH}$ & 8.87 & 8.87 & 8.85 & 8.82 \\
\hline $\mathrm{COD}, \mathrm{mgO} / \mathrm{dm}^{3}$ & 205 & 112 & 178 & 167 \\
\hline $\mathrm{NH}_{4}{ }^{+}, \mathrm{mg} / \mathrm{dm}^{3}$ & 106.7 & 39.3 & 98.3 & 110.6 \\
\hline $\mathrm{NO}_{3}{ }^{-}, \mathrm{mg} / \mathrm{dm}^{3}$ & 5.12 & 0.89 & 0.70 & 1.69 \\
\hline
\end{tabular}

Table 8. The wastewaters oxidation with sodium hypochlorite.

\begin{tabular}{|c|c|c|c|c|}
\hline \multirow{2}{*}{ Index } & \multicolumn{4}{|c|}{ Dose, $\mathrm{mg} / \mathrm{dm}^{3}$} \\
\cline { 2 - 5 } & 10 & 20 & 30 & 40 \\
\hline $\mathrm{pH}$ & 8.27 & 8.33 & 8.07 & 8.25 \\
\hline $\mathrm{COD}, \mathrm{mgO} / \mathrm{dm}^{3}$ & 124 & 300 & 331 & 350 \\
\hline $\mathrm{NH}_{4}{ }^{+}, \mathrm{mg} / \mathrm{dm}^{3}$ & 79.7 & 90.5 & 99.7 & 127.98 \\
\hline
\end{tabular}

According to Table 7 and 8 the optimal reagent is potassium permanganate and its optimal dose is $10 \mathrm{mg} / \mathrm{dm} 3$.

The results of intensification of wastewater oxidation are shown in Table 9.

Table 9. The results of intensification of wastewater oxidation.

\begin{tabular}{|c|c|c|c|c|}
\hline \multirow{2}{*}{ Intensification method } & \multicolumn{4}{|c|}{ Index } \\
\cline { 2 - 5 } & $\mathrm{pH}$ & $\begin{array}{c}\mathrm{COD}, \\
\mathrm{mgO} / \mathrm{dm}^{3}\end{array}$ & $\begin{array}{c}\mathrm{NH}_{4}^{+}, \\
\mathrm{mg} / \mathrm{dm}^{3}\end{array}$ & $\mathrm{NO}_{3}{ }^{-}, \mathrm{mg} / \mathrm{dm}^{3}$ \\
\hline Heating to $60^{\circ} \mathrm{C}$ & 8.17 & 99 & 46.1 & 0.80 \\
\hline Microwave irradiation & 8.13 & 150 & 52.1 & 1.07 \\
\hline Aeration & 7.89 & 98 & 38.2 & 0.55 \\
\hline Ozonation & 8.02 & 41 & 26.5 & 0.15 \\
\hline
\end{tabular}

\section{Discussions}

According to obtained data (Table 2-4) the most effects of the COD removal (64.2\%) and nitrates removal (68.2\%) were achieved after coagulation with the reagent "Akva-Aurat 30" $\left(50 \mathrm{mg} / \mathrm{dm}^{3}\right)$. The ammonium concentration was the same during experiment.

While coagulation with the iron-containing reagents (ferrous sulphate and ferric chloride) at doses 50 and $90 \mathrm{mg} / \mathrm{dm}^{3}$ during 20 minutes there was no floc formation. Floc formation with ferric chloride began with the dose $120 \mathrm{mg} / \mathrm{dm}^{3}$, while with ferrous sulphate floc formation began with simultaneous adding the coagulant (dose $120 \mathrm{mg} / \mathrm{dm}^{3}$ ) and acidification to $\mathrm{pH}=4.74$. Further research with these coagulants was not conducted due to economical inexpedience of their usage.

According to Table 5-6 the flocculant decreases the concentration of the organic matters additionally to $4-6 \%$. The most effective flocculant was polyacrylamide (dose $1 \mathrm{mg} / \mathrm{dm}^{3}$ ): it reduces COD on $70.1 \%$, suspended matters on $96 \%$ and nitrates on $75.9 \%$. Wastewater $\mathrm{pH}$ after filtration was 6.58 .

Thus, based on the result of coagulation, the optimal dose of coagulant "Akva-Aurat 30 " is $50 \mathrm{mg} / \mathrm{dm}^{3}$ and the optimal dose of flocculant Polyacrylamide is $1 \mathrm{mg} / \mathrm{dm}^{3}$.

According to the oxidation results (Table 7-9) the optimal reagent for wastewater oxidation was potassium permanganate $\left(\right.$ dose $\left.10 \mathrm{mg} / \mathrm{dm}^{3}\right)$, which decreases COD on $90.8 \%$, ammonium on $74 \%$ and nitrates on $82.5 \%$. Two-staged oxidation by potassium permanganate and ozonation with intermediate filtration improved an effect of the COD removal to $96.6 \%$, ammonium removal to $82.4 \%$ and nitrates removal to $97.1 \%$.

Based on the conducted research the following technological scheme WWTP for small settlements in the arctic regions is suggested (Figure 2). 


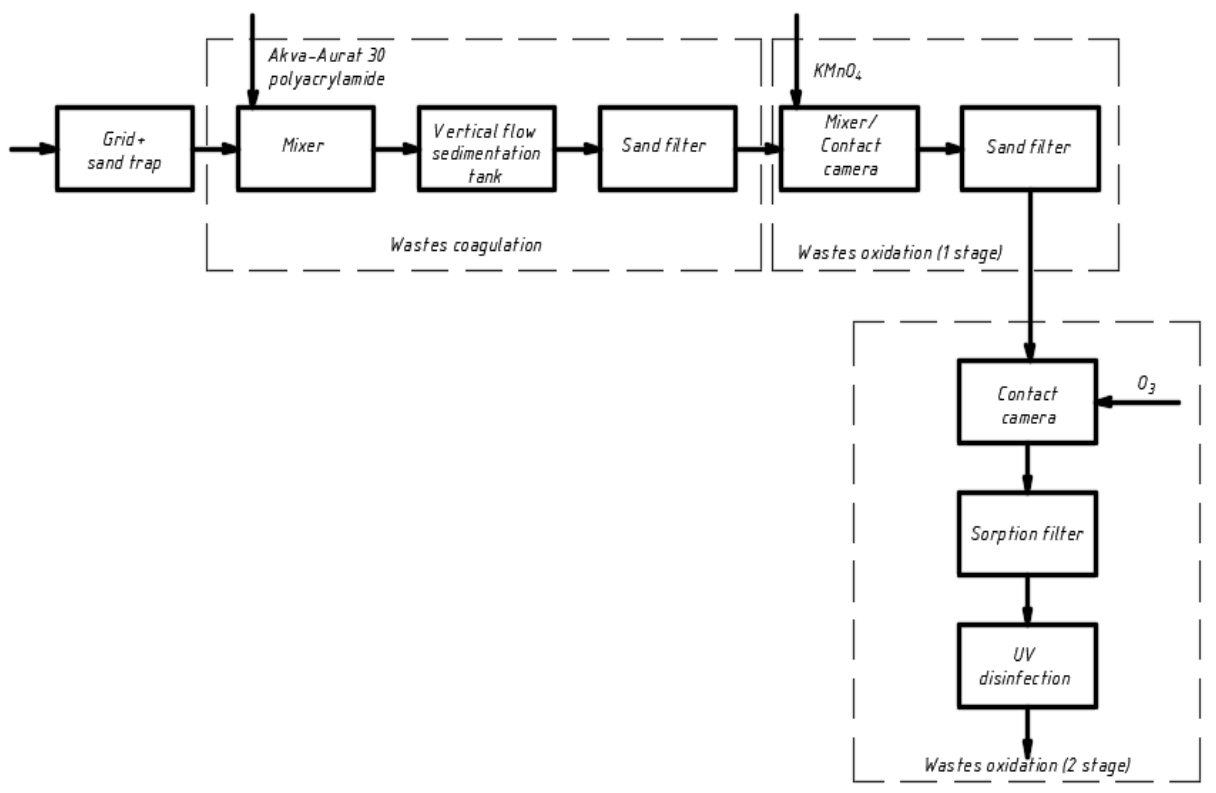

Fig. 2. Technological scheme of small settlements wastewaters treatment in the arctic regions.

\section{Conclusions}

Based on the conducted research results on possible replacement of the biological treatment unit to physical-chemical one for wastewaters of small arctic settlements, following conclusions can be made:

- In small settlements, located in the regions of Far North or equal to these conditions, the biological wastewater treatment is a difficult process to realize because of the severe climate conditions, irregularity of wastewater income to the treatment plants, difficult exploitation, shortage of qualified staff and other reasons.

- Published research of the Russian and foreign scientists confirm the possibility of total replacement of the biological wastewater treatment schemes to physical-chemical one: coagulation, oxidation and others.

- Coagulant "Akva-Aurat 30" (dose $50 \mathrm{mg} / \mathrm{dm}^{3}$ ) and flocculant Polyacrylamide (dose 1 $\mathrm{mg} / \mathrm{dm}^{3}$ ) were the most effective ones according to data of trial coagulation.

- The most effective reduction of COD on $96.6 \%$ was achieved by two-staged oxidation with potassium permanganate (dose $10 \mathrm{mg} / \mathrm{dm}^{3}$ ) and ozonation with intermediate filtration on sand and carbon filters. The concentration of ammonium-ions decreased on $82.4 \%$, nitrate-ions on $97.1 \%$, the suspended matters were removed on $96 \%$ according to this technological scheme.

- $\quad$ Based to the laboratory research the following technological scheme of wastewater treatment was suggested:

Mechanical treatment (grid sand trap) - Coagulation ("Akva-Aurat 30" polyacrylamide) Oxidation $1^{\text {st }}$ stage (potassium permanganate and sand filter) - Oxidation $2^{\text {nd }}$ stage (ozonation and sorption filters) - Ultraviolet disinfection.

In spite of the significant organic contaminants reduction in wastewater during experience, the impurities concentrations, required by Russian standard documentation for dumping into fishery water objects, were not achieved. 
In conjunction with the foregoing, further, the more detailed researches on the dynamics of wastewater contaminants reduction while physical-chemical treatment are supposed. Experimental control of another methods of physical-chemical wastewater treatment, as well as changing of the reagents dose and their order of adding into the wastewater samples is planned. It is necessary to note that also should be researched the hazard class of the wastewater sludge.

\section{References}

1. E. Vialkova, S. Maksimova, IOP Conf. Ser.: Earth Environ. Sci.б 181012035 (2018) DOI: $10.1088 / 1755-1315 / 181 / 1 / 012035$

2. V.Ia. Kofman, Water supply and wastewater disposal in the Arctic region: Greenland, Canada, USA (a review), 6, 56-64 (2019)

3. Journal of the Northern Territories Water and Waste Association http://ntwwa.com/wpcontent/uploads/2018/03/NTWWA_Journal_2017.pdf

4. R. Gunnarsdóttir, P.D. Jenssen, et al., Ecol. Eng., 50 76-85 (2013) DOI: 10.1016/j.ecoleng.2012.04.025

5. S. Heaven, A.C. Lock, L.N. Pak, M.K. Rspaev, Water Sci. Technol., 48 25-33 (2003) DOI: 10.2166/wst.2003.0078

6. Waste Stabilization Ponds for Waste Water Treatment, Anaerobic Pon http://home.eng.iastate.edu/*tge/ce421-521/Fernando\%20J.\%20Trevino\%20Quiroga. pdf. DOI: 10.1680/ensu.10.00052

7. A.M. Paruch, T. Mæhlum, et al., Water Sci. Technol., 63 776-781 (2011) DOI: 10.2166/wst.2011.308

8. H. Gao, Y.D. Scherson, G.F. Wells, Environ Sci.: Processes \& Impacts, 16 1223-1246 (2014) DOI: 10.1039/c4em00069b

9. Z. Du, H. Li, T. Gu, Biotechnol. Adv., 25 464-482 (2007) DOI: 10.1016/j.biotechadv.2007.05.004

10. H. Liu, R. Ramnarayanan, B. Logan Environ, Sci. Technol., 38 2281-2285 (2004) DOI: 10.1021/es034923g

11. V. Ia. Kofman, Water supply and wastewater disposal in the Arctic Region: advanced technical solution (a review), 7, 56-64 (2019)

12. N. LaBarge, Y.D. Yilmazel, et al., Bioelectrochem, 113 20-25 (2007) DOI: 10.1016/j.bioelechem.2016.08.003

13. A.S. Stasinakis, Global NEST Journal, 10 376-385 (2008) DOI: 10.30955/gnj.000598

14. R. Andreozzi, V. Caprio, et al., Catal. Today, 53 51-59 (1999) DOI: 10.1016/S09205861(99)00102-9

15. Y. Deng, R. Zhao, Curr Pollution Rep., 1 167-176 (2015)DOI: 10.1007/s40726-0150015-Z

16. M.A. Oturan, J. Aaron, Crit. Rev. Env. Sci. Technol, 44 2577-2641 (2014) DOI: 10.1080/10643389.2013.829765

17. E. Brillas, J. Casado, Chemosphere, 47 241-248 (2002) DOI: 10.1016/S00456535(01)00221-1

18. M.N. Chong, B. Jin, et al., Water Res., 44 2997-3027 (2010) DOI: 10.1016/j.watres.2010.02.039 
19. A.V. Zhelovickaya, E.A. Ermolaeva, A.F. Dresvyannikov, Vestnik Kazanskogo Universiteta 211-229 (2008)

20. E. Brillas, E. Mur, et al., Appl. Catal. B: Environ., 16 31-42 (1997) DOI:10.1016/s0926-3373(97)00059-3

21. G. Chen, Sep. Purif. Technol., 38 11-41 (2004) DOI: 10.1016/j.seppur.2003.10.006

22. U. Kurt, M. T. Gonullu, F. Ilhan, K. Varinca, Environmental Engineering Science, 25, 153-161 (2008) DOI: 10.1089/ees.2006.0132 